Article No 230

DOI: https://doi.org/10.26881/srg.2020.7.05

Citation:

Dzienisiewicz, D., Dzienisiewicz, M. (2020). Praktyka transkrypcji

współczesnego języka rosyjskiego na znaki polskiego alfabetu

w świetle reguł Wydawnictwa Naukowego PWN (na podstawie eksperymentu badawczego).

Studia Rossica Gedanensia, 7: 59-70.

DOI: https://doi.org/10.26881/srg.2020.7.05

\title{
PRAKTYKA TRANSKRYPCJI WSPÓŁCZESNEGO JEZYKA ROSYJSKIEGO NA ZNAKI POLSKIEGO ALFABETU W ŚWIETLE REGU€ WYDAWNICTWA NAUKOWEGO PWN (NA PODSTAWIE EKSPERYMENTU BADAWCZEGO)
}

\section{DANIEL DZIENISIEWICZ}

Uniwersytet im. Adama Mickiewicza w Poznaniu / Adam Mickiewicz University Wydział Neofilologii / Faculty of Modern Languages and Literatures Instytut Etnolingwistyki / Institute of Ethnolinguistics

Al. Niepodległości 4, 61-874 Poznań, Polska / Al. Niepodległości 4, 61-874 Poznań, Poland E-mail: dzienis@amu.edu.pl

ORCID: https://orcid.org/0000-0003-0400-5143

\section{MARIA DZIENISIEWICZ}

Uniwersytet im. Adama Mickiewicza w Poznaniu / Adam Mickiewicz University Wydział Neofilologii / Faculty of Modern Languages and Literatures

Instytut Filologii Rosyjskiej i Ukraińskiej / Institute of Russian and Ukrainian Philology Al. Niepodległości 4, 61-874 Poznań, Polska / Al. Niepodległości 4, 61-874 Poznań, Poland

E-mail: maria.z.wojcik@gmail.com

ORCID: http://orcid.org/0000-0001-6140-6889

(Nadesłano / Received 2.09.2020. Zaakceptowano / Accepted 5.10.2020) 


\section{Abstract \\ The practice of transcription from Modern Russian into Polish in the light of the rules of the Polish Scientific Publishers PWN (based on a research experiment)}

The article discusses the results of a research experiment performed on a group of students at Adam Mickiewicz University in Poznań. The students were asked to transcribe Russian texts into the Polish alphabet without any previous training in transcription. The aim of the study was to examine natural inclinations of Polish native speakers in terms of the transcription of the Russian language and to compare the results of the study with the rules of transcription and transliteration used by the Polish Scientific Publishers PWN. Another aim of the study was to confront the obtained data against the outcomes of the analysis of the transcription of Russian texts in the Polish press.

Key words: transcription, transliteration, spelling, Polish, Russian

\section{Резюме}

Практика транскрипции с современного русского языка на польский в сопоставлении с правилами Государственного научного издательства PWN (на основе исследовательского эксперимента)

В статье рассматриваются результаты исследовательского эксперимента, проведенного на группе студентов Университета им. Адама Мицкевича в Познани. Студенты получили задачу транскрибировать текст, написанный на русском языке, на буквы польского алфавита без предварительной подготовки в области транскрипции. Цель исследования заключалась в изучении естественных навыков в сфере транскрипции русского языка польским алфавитом и сравнении результатов с правилами транскрипции и транслитерации Государственного научного издательства PWN. Следующим этапом исследования являлось сопоставление полученных данных с результатами изучения транскрипции русского языка, проведенного на материале польских СМИ.

Ключевые слова: транскрипция, транслитерация, правописание, польский язык, русский язык

\section{Wprowadzenie}

Mieczysław Szymczak stwierdza, że alfabety cyrylickie nowożytnych języków słowiańskich, w tym języka rosyjskiego, mogą być oddawane w polskim zapisie za pomocą systemu transliteracji lub transkrypcji. Badacz objaśnia pojęcie transliteracji jako konwersję pisma polegającą na oddawaniu liter jednego alfabetu za pomocą liter innego alfabetu, które w razie potrzeby mogą zostać zaopatrzone w nietypowe znaki dia- 
krytyczne (Szymczak 1992: 149). W systemie transliteracji (w odróżnieniu od transkrypcji) nie uwzględnia się fonetycznych właściwości głosek oznaczanych przez litery w alfabecie transliterowanym. Irena Dulewiczowa, podobnie jak Edward Polański, precyzuje pojęcie transliteracji, wskazując na konwersję nie liter, a znaków określonego alfabetu na znaki innego alfabetu (Dulewiczowa 1981: 12; Polański 1996: 85; por. Dulewiczowa 1993). Jest to system, który nie uwzględnia cech fonetycznych języka w centrum uwagi pozostaje bowiem grafia, co sprawia, że stosowany jest on w pracach naukowych oraz opisach bibliotecznych i katalogowych. Jak zauważa Dulewiczowa, dzięki transliteracji upraszcza się nie tylko zapis tekstu rosyjskiego łacinką, ale jednocześnie umożliwia się przywrócenie oryginalnej postaci danego tekstu. Transliteracja stosowana $\mathrm{w}$ obrębie bibliotek naukowych jest kompatybilna $\mathrm{z}$ międzynarodowym systemem konwersji alfabetu rosyjskiego i uwzględnia wytyczne Międzynarodowej Organizacji Normalizacyjnej ISO (International Organization for Standardization) ${ }^{1}$ (Dulewiczowa 1981: 13).

Z kolei istotę transkrypcji stanowi zastępowanie dźwięków danego języka przy pomocy znaków składających się na alfabet innego języka. Studiując zasady transkrypcji współczesnego języka rosyjskiego na znaki alfabetu polskiego można jednak wysunąć pewne zastrzeżenia wobec konsekwencji oddawania przez nią warstwy dźwiękowej tego języka. Na ten fakt zwraca uwagę także Dulewiczowa i w związku z tym definiuje transkrypcję jako adaptację systemu graficznego jednego języka do systemu graficznego drugiego przy uwzględnieniu wyłącznie "pewnych cech fonetycznych” obu języków. Częstokroć rozwiązania transkrypcyjne są bowiem dyktowane przez tradycję piśmienniczą będącą wynikiem formowania się - nie zawsze spójnych - zasad konwersji grażdanki na znaki alfabetu polskiego² (Dulewiczowa 1981: 17). Różnica między transliteracją i transkrypcją jest więc istotna: $\mathrm{z}$ założenia celem transliteracji jest konsekwentne oddawanie znaków jednego alfabetu przy pomocy znaków innego alfabetu, transkrypcji natomiast - oddawanie brzmienia poszczególnych głosek. W związku z powyższym inny jest również zakres zastosowania transliteracji, a inny transkrypcji, która nie wymaga naukowej ścisłości, lecz jedynie przybliżenia brzmienia. Transkrypcja, kierowana do szerokiego grona czytelników, spotykana jest w literaturze, prasie, wydawnictwach popularnych i popularnonaukowych, bibliotekach szkolnych i powszechnych (Szymczak 1992: 149).

Obowiązujące zasady transkrypcji współczesnego języka rosyjskiego zostały uchwalone przez Komitet Językoznawstwa Polskiej Akademii Nauk 20 stycznia 1956

\footnotetext{
1 Reguły transliteracji zostały zamieszczone na stronie internetowej: https://sjp.pwn.pl/zasady/30776-A-Transliteracja-wspolczesnego-alfabetu-rosyjskiego;629696.html (25.08.2020).

2 W rzeczy samej można wykazać brak konsekwencji reguł transkrypcji PWN. Na przykład, pomimo iż w definicji transkrypcji mowa jest o tym, że ma ona na celu oddawanie dźwięków określonego języka, zgodnie z zasadami transkrypcji nie należy oznaczać w zapisie tzw. akania (wymowy nieakcentowanego $o$ jako $a$ ). Nie powinno się także zaznaczać właściwej wymowy samogłosek występujących w pozycji po spółgłoskach twardych, innej od sugerowanej przez rosyjski zapis graficzny. Tak więc np. wyraz Æums powinno transkrybować się jako żit', a nie żyt', podczas gdy to właśnie drugi wariant zapisu bliższy jest wymowie rosyjskiego wyrazu. Opis tej problematyki znalazł się także w artykule Dzienisiewicz 2019.
} 


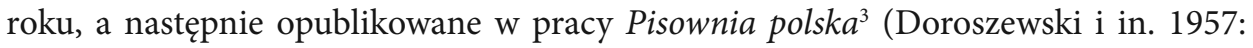
43-58). Reguły te - w szczególności rozbieżności między założeniami znajdującymi się u podstaw transkrypcji a samymi zasadami - dały asumpt do zbadania, czy oraz w jakim stopniu są one przestrzegane, a także jakie tendencje można zaobserwować w transkrypcji z języka rosyjskiego dokonywanej spontanicznie i bez przygotowania teoretycznego przez rodzimych użytkowników języka polskiego. Wstępne badanie zostało przeprowadzone na materiale tekstów publicystycznych Stanisława Michalkiewicza (dalej: SM), zawierających liczne zapożyczenia z języka rosyjskiego zapisywane w postaci transkrypcji ${ }^{4}$ Analiza wykazała częste przypadki niezgodności występujących między normą transkrypcyjną a uzusem (zob. opis wyników badań w dalszej części niniejszego artykułu). Z uwagi na fakt, że dotychczasowe analizy obejmowały wyłącznie teksty jednego autora, postanowiono przeprowadzić odrębne badanie na materiale pochodzącym od większej liczby użytkowników języka polskiego posługujących się językiem rosyjskim w stopniu komunikatywnym lub uczących się tego języka, lecz nieznających szczegółowych zasad transkrypcji i transliteracji. Celem przedsięwzięcia było zatem wykrycie tendencji w zakresie intuicyjnej praktyki transkrypcyjnej u osób nielegitymujących się znajomością szczegółowych reguł transpozycji grażdanki na znaki polskiego alfabetu, a także porównanie uzyskanych wyników z przeprowadzonym wcześniej badaniem.

\section{Eksperyment badawczy}

W celu pozyskania przetranskrybowanych tekstów w roku akademickim 2017/2018 przeprowadzono eksperyment badawczy na grupie studentów Uniwersytetu im. Adama Mickiewicza w Poznaniu. W badaniu wzięło udział 31 studentów drugiego roku studiów licencjackich w zakresie filologii rosyjskiej, filologii rosyjskiej z filologią angielską, filologii rosyjsko-ukraińskiej oraz filologii rosyjskiej z lingwistyką stosowaną. Wykorzystano 31 odrębnych fragmentów tekstu napisanych w języku rosyjskim, z których każdy składał się z kilkudziesięciu słów. Teksty stanowiące podstawę badania zostały zaczerpnięte ze strony www.kommersant.ru, a ich treść cechowała się dużą różnorodnością tematyczną - dotyczyły one takich dziedzin, jak polityka, gospodarka, sport czy kultura. Po otrzymaniu fragmentów tekstu studenci zostali poproszeni o wykonanie polecenia, które brzmiało: Zapisz poniższy tekst przy pomocy polskich znaków. Celowo w instrukcji nie użyto wyrazów transkrypcja oraz transliteracja, aby nie sugerować preferowanego zapisu oraz pozwolić osobom wykonującym zadanie zaprezentować ich naturalne inklinacje. Kolejnym etapem badania było sprawdzenie zgodności uzyskanych rezultatów z zasadami transkrypcji oraz transliteracji współczesnego języka rosyjskiego zalecanymi przez Państwowe Wydawnictwo Naukowe. Poniżej przedstawiono przykładowy tekst, który następnie został zapisany za pomocą znaków polskiego alfabetu:

\footnotetext{
3 Szczegółową listę reguł zob. także na stronie internetowej: https://sjp.pwn.pl/zasady/308-76-BTranskrypcja-wspolczesnego-alfabetu-rosyjskiego;629697.html (25.08.2020).

4 Informacje na ten temat również zostały zawarte we wspomnianym wcześniej artykule (Dzienisiewicz 2019).
} 
Пресс-секретарь президента России Дмитрий Песков отмел позже любые мои подозрения в том, что обсуждалась тема Сирийского национального конгресса (впрочем, сам Сергей Лавров еще несколько дней назад заявлял, что конгресс состоится, правда, неизвестно, где и когда). А министр иностранных дел Турции с удовлетворением констатировал, что сирийские курды в этом конгрессе участвовать все-таки не будут (https://www. kommersant.ru/doc/3466763 (25.08.2020).

\section{Analiza materiału badawczego}

Konfrontacja badanego materiału z zasadami transkrypcji wykazała, że wśród całkowitej liczby 1637 przetranskrybowanych wyrazów wystąpiło 1245 błędów. Błędy te można podzielić na trzy główne kategorie ukazujące podstawowe operacje graficzne zniekształcające poprawny zapis:

1) dodawanie znaków - 94 błędy (7,6\% wszystkich błędów), np. udawlietworieniem, pozwoljat, budziet, bol'sze, nasl'edia, prinadljeżyt, jridićjskim, Rostjeljekoma, wproczjem, tol'ka, industrial'nyj, skolika, wyszkaljenych, dlja, staljetiju, Rostjeljekomom, cislje, sostawljajet, pozwoljat, polućatjeljami, budziet, zloupotrjebljać, kolljegi, ljubyje, jeśjo;

2) opuszczanie znaków - 228 błędów (18,3\%), np. p(r)astranstwach, ter(r)itorii, ri(e)szajuśij, iskus(s)twa, podnj(a)li, sap(i)ernika, dz(i)elo, haz(i)ajewam, wiz(i) enija, slucils(i)a, W(i)edź, mam(i)ent, $m(\boldsymbol{i}) a c ́$, gast(i)am, ri(e)szajuśij, sawi(e) rszenija, Ros(s)i(i), kongries(s)a, ter(r)itoriju, nawjerna(j)e, past(r)ojen, gotow(n) osti, $\operatorname{drugi}(\mathbf{j})$;

3) zastępowanie znaków przez inne - 923 błędy (74,1\%), np. apasajecsa, sawsjem, nikagda, atkrytowa, swojewo, ploszczadi, slućaje, sazdannyje, sjedmawa, jasna, aciercien, wtaruju, pragrammu, Jurawskij, sastawil, budta, aciewidnych, luczszego, galawu, Wladimira, Krjeml, beskrajnjeje, mjesta, nynjesznjaja, swojewo, nastojasiewo, konkretnowo, faworyt, opozycji, zakończiwszejsja, dejatelność.

Szczegółowa analiza materiału umożliwiła wyodrębnienie 62 rodzajów błędów zaobserwowanych w transkrypcji. Okazało się jednak, że większość (ponad 80\%) omyłek można odnieść wyłącznie do dziesięciu typów błędów charakteryzujących się największą częstością występowania. Należą do nich:

1) zapis litery $a$ w miejsce litery o (24,3\% wszystkich błędów), np. padsankcjonnawa, katoraje, goradach, pajawljajutsa;

2) zapis litery $j \mathrm{w}$ miejsce litery $i \mathrm{w}$ pozycji po literze oznaczającej spółgłoskę i przed literą wyrażającą samogłoskę $(19,4 \%)$, np. beskrajnjeje, mjesta, nynjesznjaja, pamnjaszczij, gdje, kupjeczjeskie;

3) brak litery $i$ w pozycji po literze oznaczającej spółgłoskę i przed literą wyrażającą samogłoskę (12,3\%), np. krom(i)e, p(i)er(i)ewody, aczewid(i)en, abstojat(i)elstwo, wstr(i)eczi;

4) zapis litery $l \mathrm{w}$ miejsce litery $\ell(8,1 \%)$, np. slućaje, ploszczadi, akruglast, raspalagajetsa, ploszczad, ustarjela;

5) oznaczanie redundantnego zmiękczenia przy pomocy litery $j(4,4 \%)$, np. pajawljajutsa, prinadljeżyt, sostawljajet, dlja, priwljekatjelno; 
6) zapis litery ćw miejsce połączenia cz (3,1\%), np. sroćno, ćastnosti, ćerez, jridićjskim, ćjelawjek, kljućjewyje;

7) zapis litery $h \mathrm{w}$ miejsce połączenia ch (2,4\%), np. ih, torgowyh, whod, klijentah, otkazah, dohodow, ramkah;

8) zapis litery $w$ w miejsce litery $g w$ końcówkach fleksyjnych form dopełniacza liczby pojedynczej (2,1\%), np. atkrytowa, padsankcjonnawa, tawo, n'earuskawa, njewo;

9) zapis połączenia $s z \mathrm{w}$ miejsce połączenia $c z(2,1 \%)$, np. szto, kanieszna, neszta, szta;

10) zapis znaku ' w miejsce litery $i(1,9 \%)$, np. wr'em'eni, n'e, n'ewazmożna, sochran'enija, int'er'esna.

Do pozostałych 52 rodzajów błędów, stanowiących ok. 20\% materiału, należą nieliczne lub jednostkowe omyłkowe zapisy. Można wśród nich wskazać m.in.:

11) zapis litery $d$ w miejsce litery $t$, np. addawat;

12) zapis litery $y$ w miejsce $i$, np. faworyt, opozycji;

13) zapis litery $n$ w miejsce $n$, np. zakończiwszejsja;

14) zapis litery ś w miejsce s', np. patrjebowaaś;

15) zapis litery $s^{\mathrm{w}} \mathrm{m}$ miejsce $s$, np. dejatelność.

Poniżej natomiast ukazano 12 rodzajów błędów charakteryzujących się największą ekstensją, tj. odstępstwa od reguł odnotowane w największej liczbie (powyżej 10) prac, czyli błędy popełnione przez największą liczbę osób:

1) zapis litery $l \mathrm{w}$ miejsce litery $\ell$ ( 27 osób);

2) brak litery $i$ w pozycji po literze oznaczającej spółgłoskę i przed literą wyrażającą samogłoskę (26 osób);

3) zapis litery $j \mathrm{w}$ miejsce litery $i \mathrm{w}$ pozycji po literze oznaczającej spółgłoskę i przed literą wyrażającą samogłoskę ( 24 osoby);

4) zapis litery $a$ w miejsce litery $o$ (19 osób);

5) oznaczanie redundantnego zmiękczenia przy pomocy litery $j$ (18 osób);

6) zapis litery $w \mathrm{w}$ miejsce litery $g \mathrm{w}$ końcówkach fleksyjnych form dopełniacza rodzaju męskiego i nijakiego liczby pojedynczej (15 osób);

7) zapis połączenia $s z \mathrm{w}$ miejsce połączenia $c z$ (15 osób);

8) zapis litery ć w miejsce połączenia $c z$ (14 osób);

9) zapis litery ć w miejsce połączenia $t^{\prime}$ (14 osób);

10) opuszczanie litery $j$ (11 osób);

11) zapis połączenia $c i$ w miejsce połączenia $c z$ (11 osób);

12) zapis litery $e$ w miejsce litery $o$ (11 osób).

Powyższe dane ukazują korelację między większością błędów zaliczonych w poczet najczęstszych oraz tych, które cechują się największą ekstensją (por. kategorie 1-8 wśród odstępstw o największym zasięgu). Jednakże jednostki należące do kategorii 9-12 spośród błędów o największej ekstensji charakteryzują się niską frekwencją, oscylującą między 1,2\% a 1,7\%. Z kolei niektóre z błędów uznanych za częste cechują się niewielką ekstensją; są to: zapis litery $h \mathrm{w}$ miejsce połączenia ch $(2,4 \%, 10$ osób) i zapis znaku 'w miejsce litery $i$ (1,9\%, 3 osoby). Powyższe obserwacje można podsumować $\mathrm{w}$ formie następującej tabeli: 
Tabela 1. Błędy cechujące się najwyższą frekwencją i największą ekstensją

\begin{tabular}{|c|c|c|}
\hline Typ błędu & Częstość (\%) & $\begin{array}{c}\text { Ekstensja } \\
\text { (liczba prac) }\end{array}$ \\
\hline zapis litery $a \mathrm{w}$ miejsce litery $o$ & 24,3 & 19 \\
\hline $\begin{array}{l}\text { zapis litery } j \text { w miejsce litery } i \text { po literze wyrażającej spółgło- } \\
\text { skę i przed literą wyrażającą samogłoskę }\end{array}$ & 19,4 & 24 \\
\hline $\begin{array}{l}\text { brak litery } i \text { w pozycji po literze wyrażającej spółgłoskę } \\
\text { i przed literą wyrażającą samogłoskę }\end{array}$ & 12,3 & 26 \\
\hline zapis litery $l \mathrm{w}$ miejsce litery $l$ & 8,1 & 27 \\
\hline oznaczanie redundantnego zmiękczenia przy pomocy litery $j$ & 4,4 & 18 \\
\hline zapis litery $c ́$ w miejsce połączenia $c z$ & 3,1 & 14 \\
\hline zapis litery $h \mathrm{w}$ miejsce połączenia $c h$ & 2,4 & 10 \\
\hline $\begin{array}{l}\text { zapis litery } w \text { w miejsce litery } g \mathrm{w} \text { końcówkach fleksyjnych } \\
\text { form dopełniacza liczby pojedynczej }\end{array}$ & 2,1 & 15 \\
\hline zapis połączenia $s z$ w miejsce połączenia $c z$ & 2,1 & 15 \\
\hline zapis znaku 'w miejsce litery $i$ & 1,9 & 3 \\
\hline opuszczanie litery $j$ & 1,7 & 11 \\
\hline zapis połączenia $c i \mathrm{w}$ miejsce połączenia $c z$ & 1,6 & 11 \\
\hline zapis litery $c ́$ w miejsce połączenia $t^{\prime}$ & 1,3 & 14 \\
\hline zapis litery $e \mathrm{w}$ miejsce litery $o$ & 1,2 & 11 \\
\hline
\end{tabular}

Źródło: opracowanie własne.

Wyniki analizy pokazują, że podczas dokonywania wyboru sposobu zapisu rosyjskiego tekstu przy pomocy znaków alfabetu polskiego studenci kierują się przede wszystkim rosyjską wymową transkrybowanych wyrazów oraz podobieństwem niektórych dźwięków języka polskiego do określonych dźwięków rosyjskich, nie zaś konwencją graficzną. Prowadzi to do intuicyjnego wyboru zapisu w formie transkrypcji. Świadczy o tym m.in. częste odzwierciedlanie akania na piśmie, zmiękczanie liter wyrażających spółgłoski za pomocą litery $j$, zapis litery $l \mathrm{w}$ miejsce litery $\ell$, zapis liter $c ́ / c i /$ $c j \mathrm{w}$ miejsce połączenia $c z$, zapis litery $w \mathrm{w}$ miejsce litery $g \mathrm{w}$ końcówkach form fleksyjnych dopełniacza rodzaju męskiego i nijakiego liczby pojedynczej, zapis połączenia $s z$ w miejsce $c z$ (np. kanieszna, szto), zapis liter śśści/ść/śćj w miejsce połączenia szcz czy zaznaczanie redundantnego zmiękczenia przy pomocy litery $j$ w pozycji po literze $l$.

Częste pomijanie litery $i \mathrm{w}$ pozycji po literach wyrażających spółgłoski i przed

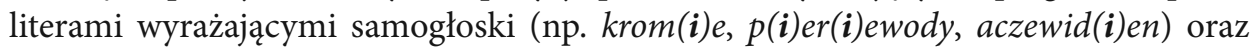
pomijanie znaku zmiękczenia (np. zametit('), akruglast('), ploszczad('), wykladywat(') sja, bud(')te) można interpretować różnorako, np. jako nieznajomość sposobu oznaczania miękkości bądź jako przekonanie o poprawności zapisu niezawierającego znaków zmiękczających, wynikające z niedostatecznej znajomości języka. Podobnie można wytłumaczyć przypadki pomijania litery $j$ (np. kupjeczjeski(j)e, zna(j)et, obsze(j) e), lecz niektóre z nich mogą być także spowodowane interferencją języka polskiego (np. sozdani(j)e, bronirowani(j)e, soglaszeni $(\mathbf{j}) e)$, w którym w zapisie rzeczowników odsłownych na -anie/-enie litera $j$ nie występuje. Zapis litery $e$ w miejsce litery $o$ naj- 
prawdopodobniej także wynika z nieznajomości poprawnej wymowy wyrazów, które w rosyjskim tekście zostały zapisane przy użyciu litery e zamiast $\ddot{e}$ (np. ostajemsja, putjem, partner). Pozostałe błędy w większości nie cechują się w badanym materiale wysokim stopniem regularności (tj. zarówno frekwencji, jak i ekstensji).

Warto byłoby ponadto odnotować, że niektóre $\mathrm{z}$ rozpatrywanych zapisów uznanych za błędy w świetle reguł transkrypcji odpowiadają zasadom transliteracji. Przykładowo wedle reguł transliteracji rosyjska litera $e$ winna być zapisywana jako polska litera $e$ bez względu na pozycję, w której się znajduje (por. zapisy krome, perewody, aczewiden). Również niezmiękczona litera $\pi \mathrm{w}$ transliteracji oddawana jest zawsze jako $l$ (por. np. slućaje, ploszczadi, akruglast), a litera $x$ - zawsze jako $h$ (por. ih, torgo$w y \boldsymbol{h}$, whod). Wymienione zapisy zostały wcześniej zaliczone do grupy błędów częstych oraz cechujących się dużą ekstensją. Wskazują one na to, że w kilku przypadkach badane osoby mają skłonność do nieświadomego wyboru zapisu w formie transliteracji.

\section{Wyniki badania w świetle rezultatów dotychczasowych analiz}

Kolejnym etapem była konfrontacja wyników uzyskanych w drodze eksperymentu badawczego z rezultatami badań nad praktyką transpozycyjną SM. Celem porównania było sprawdzenie, czy błędy w transkrypcji z tekstów jednego autora (relatywnie często stosującego transkrypcję z języka rosyjskiego w swojej publicystyce) występują w podobnych proporcjach w tekstach większej liczby osób posługujących się językiem rosyjskim - innymi słowy: czy są one reprezentatywne dla większej grupy osób dokonujących transkrypcji. Z felietonów SM z lat 2003-2015 wyekscerpowano 334 rosyjskie wyrazy przetranskrybowane na znaki alfabetu polskiego, łącznie zawierające 111 błędów, które zostały ujęte w następujące kategorie

1) zapis litery $a \mathrm{w}$ miejsce litery $o$, np. palitiki, popałam;

2) oznaczanie miękkości litery $l$ za pomocą litery $i$ w pozycji przed literami $a$ i $e$, np. jawliajetsia, kliewietał;

3) nieoznaczanie miękkości spółgłosek przed literą $e$ za pomocą litery $i$, np. biznesmien, realizujet;

4) oznaczanie miękkości w pozycjach, w których ta nie powinna być oddawana, np. Giermańcy, nocz';

5) pomijanie znaku zmiękczenia, np. jest, wosiem;

6) zapis litery $i$ oraz $j w$ pozycji po literach oddających twarde spółgłoski (w miejsce litery $y$ ), np. dierżitsia, skażi;

7) pomijanie litery $j \mathrm{w}$ transkrypcji liter oddających samogłoski jotowane (je, jo, $j u, j a)$ występujących po innych literach oddających samogłoski, np. obwinienie, riezanie;

8) nieuwzględnianie obecności miękkiego znaku występującego w pisowni rosyjskiej $\mathrm{w}$ funkcji rozdzielającej przed literami oddającymi samogłoski jotowane, transkrybowanymi w tej pozycji jako $j$ i litera oddająca samogłoskę, np. sudia, swinia;

5 Rezultaty badania przeprowadzonego na materiale tekstów SM zaczerpnięto z artykułu Dzienisiewicz 2019. 
9) niezapisywanie geminat $w$ pozycjach, w których te występują w oryginalnej pisowni rosyjskiej, np. agriesor, artileristy;

10) zapis nazw narodowości wielką literą, np. Amierikańcy, Jewriej;

11) zapis litery $w \mathrm{w}$ miejsce litery $g \mathrm{w}$ końcówkach fleksyjnych form dopełniacza liczby pojedynczej przymiotników rodzaju męskiego i nijakiego, np. drugawo, absoliutnowo;

12) brak litery $i$ po literze oznaczającej spółgłoskę przed połączeniem je, np. sagłasje, sogłasje;

13) zapis litery ś w miejsce litery $s$ i znaku zmiękczenia, np. sbyliś;

14) zapis litery $y$ w miejsce litery $i$, np. psychuszka, zimnyj;

15) zapis litery $d$ w miejsce litery $t$, np. adstawku, odnoszenij;

16) zapis litery $e \mathrm{w}$ miejsce litery o, np. rieportiera, żestkoj;

17) zapis połączenia $s z \mathrm{w}$ miejsce litery $s$, np. szcziot;

18) zapis litery ś w miejsce litery $s, n p$. jeśli;

19) zapis litery o w miejsce litery $a$, np. rozum;

20) zapis litery $a$ w miejsce litery o, np. drugawo;

21) zapis litery $n \mathrm{w}$ miejsce połączenia $s z$, np. uchudnit;

22) zapis litery $t$ w miejsce litery $k$, np. wypustnik;

23) zapis litery $b$ w miejsce litery $w$, np. simbot;

24) zapis litery $a \mathrm{w}$ miejsce litery $e$, np. białorusskoro;

25) zapis litery $r$ w miejsce $g$, np. białorusskoro;

26) brak dywizu, np. polskoukrainskije;

27) błędny szyk liter, np. agiersor.

W toku analizy porównawczej wyodrębniono rodzaje błędów, które wystąpiły zarówno w pracach studentów, jak i w wyrazach transkrybowanych przez SM. Należą do nich ${ }^{6}$ :

1) zapis litery $a$ w miejsce litery $o: 302 / 1245$ (24,3\%), 36/111 (32,4\%);

2) nieoznaczanie miękkości liter oddających spółgłoski w pozycji przed literami wyrażającymi samogłoski za pomocą litery $i: 153 / 1245$ (12,3\%), 9/111 (8,1\%);

3) oznaczanie miękkości w pozycjach, w których ta nie powinna być oddawana: 79/1245 (6,3\%), 4/111 (3,6\%);

4) zapis litery $w \mathrm{w}$ miejsce litery $g \mathrm{w}$ końcówkach fleksyjnych form dopełniacza rodzaju męskiego i nijakiego liczby pojedynczej: 26/1245 (2,1\%), 4/111 (3,6\%);

5) pomijanie znaku zmiękczenia: 22/1245 (1,8\%), 4/111 (3,6\%);

6) pomijanie litery $j w$ transkrypcji liter wyrażających samogłoski jotowane (je, jo, $j u, j a)$ występujących po literach wyrażających inne samogłoski: 21/1245 (1,7\%), $3 / 111(2,7 \%)$;

7) zapis litery e w miejsce litery $o: 15 / 1245(1,2 \%), 2 / 111(1,8 \%)$;

6 Obok każdej kategorii po dwukropku podawana jest liczba wchodzących w jej skład omyłek zaobserwowanych w pracach studentów w stosunku do całkowitej liczby popełnionych przez nich błędów, natomiast $\mathrm{w}$ nawiasach przytaczany jest procent błędów, jaki stanowi ta liczba. Po przecinku podawane są analogiczne wartości uzyskane w rezultacie badania przeprowadzonego na materiale tekstów SM. 
8) niezapisywanie geminat $\mathrm{w}$ pozycjach, w których występują one $\mathrm{w}$ pisowni rosyjskiej: 10/1245 (0,8\%), 4/111 (3,6\%);

9) zapis litery $i$ oraz $j$ po literach oddających twarde spółgłoski (w miejsce litery $y$ ): 9/1245 (0,7\%), 8/111 (7,2\%);

10) oznaczanie miękkości litery $l$ za pomocą litery $i$ przed literami wyrażającymi samogłoski: 9/1245 (0,7\%), 10/111 (9\%);

11) zapis litery $y$ w miejsce litery $i: 2 / 1245(0,2 \%), 5 / 111(4,5 \%)$;

12) zapis litery $d$ w miejsce litery $t: 1 / 1245(0,1 \%), 2 / 111(1,8 \%)$.

Jak wynika z powyższych danych, tylko kategorie 1-4 zawierają błędy stanowiące powyżej $2 \%$ ogólnej liczby błędów popełnionych zarówno przez studentów, jak i przez SM. W transkrypcjach SM zaobserwowano za to wiele błędów, które w pracach studentów występowały rzadko i cechowały się niewielką ekstensją. Można natomiast wyodrębnić 10 kategorii, które charakteryzowały się wysoką frekwencją i ekstensją $\mathrm{w}$ badaniu przeprowadzonym na grupie studentów, lecz niewystępujących w tekstach SM. Są to:

1) zapis litery $j \mathrm{w}$ miejsce litery $i \mathrm{w}$ pozycji po literze oddającej spółgłoskę i przed literą oddającą samogłoskę;

2) zapis litery $l \mathrm{w}$ miejsce litery $l$;

3) oznaczanie redundantnego zmiękczenia przy pomocy litery $j$;

4) zapis litery $c ́$ w miejsce połączenia $c z$;

5) zapis litery $h \mathrm{w}$ miejsce połączenia $c h$;

6) zapis połączenia $s z \mathrm{w}$ miejsce połączenia $c z$;

7) zapis połączenia $c i \mathrm{w}$ miejsce połączenia $c z$;

8) zapis litery ś w miejsce połączenia $s z c z$;

9) zapis litery $c ́$ w miejsce połączenia $t^{\prime}$;

10) oznaczanie redundantnego zmiękczenia przy pomocy litery $i$.

Unaocznia to znaczące różnice w zakresie rodzajów błędów popełnianych przez studentów oraz SM, jak również wskazuje na rozbieżności w obszarze ich dystrybucji.

\section{Podsumowanie}

Celem przeprowadzonych analiz było wykrycie kierunku intuicyjnej praktyki transkrypcyjnej użytkowników języka polskiego posługujących się językiem rosyjskim w stopniu średnio zaawansowanym i nieznających szczegółowych reguł transkrypcji grażdanki na znaki alfabetu polskiego, a także porównanie uzyskanych wyników z rezultatem analizy zapisu zapożyczeń $\mathrm{z}$ języka rosyjskiego zamieszczanych $\mathrm{w}$ felietonach SM. Jako punkt wyjścia dla badania posłużyły reguły Wydawnictwa PWN dotyczące zasad transkrypcji i transliteracji współczesnego języka rosyjskiego na znaki alfabetu polskiego.

Analiza materiału badawczego w pierwszej części badania wykazała 1245 błędów w 1637 przetranskrybowanych wyrazach. Na tej podstawie wyodrębniono trzy główne kategorie błędów (dodawanie znaków, ich opuszczanie oraz zastępowanie innymi). Szczegółowe badanie ukazało natomiast 62 kategorie błędów w transkrypcji współczesnego języka rosyjskiego na znaki alfabetu polskiego. Należy przy tym podkreślić, 
że dziesięć spośród nich, charakteryzujących się największą częstością występowania, stanowi więcej aniżeli $80 \%$ materiału. W skład pozostałych 52 rodzajów błędów wchodzą pomyłki nieliczne bądź jednostkowe. Wyodrębniono także 12 rodzajów błędów cechujących się największą ekstensją (tj. błędów odnotowanych co najmniej w 10 pracach). Przedstawione w niniejszym artykule dane wykazują zależność występującą między większością błędów zaliczonych do grupy najczęstszych odstępstw oraz błędów cechujących się największą ekstensją. Uwagę zwraca jednak fakt, że część błędów o największej ekstensji charakteryzuje się niską frekwencją (jej wartość waha się między $1,2 \%$ a $1,7 \%$ ), podczas gdy niektóre z błędów uznanych za częste charakteryzuje niewielka ekstensja.

Rezultaty badań wykazują ponadto, że podczas eksperymentu studenci sugerowali się rosyjską wymową transkrybowanych wyrazów, a także podobieństwem niektórych dźwięków języka polskiego do określonych dźwięków rosyjskich, a nie ich zapisem graficznym. Kolejną przyczyną niewłaściwego zapisu transkrypcyjnego może być nieznajomość poprawnej wymowy wyrazów rosyjskich. Należałoby przy tym odnotować, że niektóre z rozpatrywanych zapisów uznawanych za błędy w świetle reguł transkrypcji wpisują się w zasady transliteracji.

Następnie odwołano się do wyników analizy 334 rosyjskich wyrazów wyekscerpowanych z felietonów SM z lat 2003-2015, wśród których odnotowano 111 błędów. Celem tego etapu badania było porównanie i sprawdzenie, czy błędy w transkrypcji trafiające się w tekstach polskiego publicysty są reprezentatywne dla większej grupy osób dokonujących transkrypcji. W wyniku analizy porównawczej ujawniono takie kategorie błędów, które wystąiły zarówno w transkrypcji wykonanej przez studentów, jak i w wyrazach wyodrębnionych z felietonów SM. Warto podkreślić, że generalnie SM popełnia mniej błędów (zaobserwowano 111 błędów w 324 transkrybowanych wyrazach; por. 1245 błędów w 1637 wyrazach w pierwszym badaniu). Jak wynika z przedstawionych $\mathrm{w}$ niniejszej pracy danych, jedynie cztery kategorie zawierają omyłki stanowiące powyżej $2 \%$ ogólnej liczby błędów zaobserwowanych u studentów i SM. W transkrypcjach SM odnotowano natomiast wiele błędów, które w pracach studentów charakteryzowały się niewielką ekstensją i występowały rzadko. Z drugiej strony, można wyodrębnić 10 kategorii, które charakteryzowały się wysoką frekwencją i ekstensją w badaniu przeprowadzonym na grupie studentów, nie odnotowanych jednak w tekstach SM. Świadczy to o znaczących różnicach w zakresie rodzajów błędów popełnianych przez studentów i SM oraz skali ich użycia. Szczególnie zastanawiająca wydaje się obecność w pracach studentów takich błędów, jakie nie występują w tekstach SM. Być może przyczyn ich występowania należy doszukiwać się w częstszym kontakcie osób żyjących w okresie PRL (a do takich zalicza się SM) z tekstem transkrybowanym. Powodem może być też indywidualna skłonność SM do stosowania niektórych zapisów.

Podsumowując powyższe rozważania, należałoby stwierdzić, że eksperyment ukazał liczne przypadki niezgodności między normatywnymi postulatami dotyczącymi transkrypcji języka rosyjskiego a uzusem. Tendencje te można zaobserwować zarówno wśród badanych studentów, jak i w felietonistyce SM. Nasuwa się zatem pytanie, czy nie byłaby zasadna próba redefinicji obowiązujących reguł transkrypcji i wypracowanie na podstawie zgromadzonych danych empirycznych nowego modelu, tj. systemu 
opartego nie na regułach odwołujących się do zapisu tradycyjnego, lecz na nawykach współczesnych użytkowników polszczyzny. Nie ulega wątpliwości, że materiały tekstowe dla takiego przedsięwzięcia należałoby uzyskać w wyniku starannie zaprojektowanego eksperymentu badawczego, zakrojonego na znacznie szerszą skalę (m.in. $\mathrm{z}$ uwzględnieniem różnych grupy wiekowych o zróżnicowanym poziomie znajomości języka) niż analizy przedstawione w niniejszym tekście, stanowiące jedynie przyczynek do dyskusji nad kształtem zasad transkrypcji współczesnego języka rosyjskiego.

\section{Bibliografia / References}

Doroszewski, W. i in. (1957). Pisownia polska. Przepisy - słowniczek. Wyd. 12. Wrocław: Zakład im. Ossolińskich, Wydawnictwo PAN.

Dulewiczowa, I. (1981). Transkrypcja i transliteracja wyrazów rosyjskich. Warszawa: Wydawnictwo Naukowe PWN

Dulewiczowa, I. (1993). Gramatyka konfrontatywna rosyjsko-polska. Fonetyka i fonologia. Grafia i ortografia. Warszawa: Slawistyczny Ośrodek Wydawniczy „Omnitech Press”.

Dzienisiewicz, D. (2019). O (nie)przestrzeganiu zasad transkrypcji współczesnego języka rosyjskiego (na przykładzie felietonistyki Stanisława Michalkiewicza). Slavia Orientalis, LXVIII: 167-187.

Polański, E. (Red.). (1996). Nowy słownik ortograficzny PWN wraz z zasadami pisowni i interpunkcji. Warszawa: Wydawnictwo Naukowe PWN.

Szymczak, M. (Red.). (1992). Słownik ortograficzny języka polskiego wraz z zasadami pisowni i interpunkcji. Warszawa: Wydawnictwo Naukowe PWN.

\section{Źródła elektroniczne / Electronic sources}

https://sjp.pwn.pl/zasady/307-76-A-Transliteracja-wspolczesnego-alfabetu-rosyjskiego;629696.html (dostęp 25.08.2020).

https://sjp.pwn.pl/zasady/308-76-B-Transkrypcja-wspolczesnego-alfabetu-rosyjskiego;629697.html (dostęp 25.08.2020).

https://www.kommersant.ru/doc/3466763 (dostęp 25.08.2020).

Competing interests: The authors declare that they have no conflict of interests. 